\title{
PENDEKATAN KONSTURKTIVISME DENGAN MODEL PEMBELAJARAN GENERATIF GUNA MENINGKATKAN KEMAMPUAN KOMUNIKASI DAN KONEKSI MATEMATIS SERTA SELF EFFICACY MAHASISWA CALON GURU DI KOTA CIMAHI
}

\author{
1) Eva Dwi Minarti, ${ }^{2)}$ Puji Nurfauziah \\ ${ }^{1)}$ eva.arti@yahoo.co.id, ${ }^{2)}$ puji_fauziahahmad@yahoo.com \\ ${ }^{1,2)}$ STKIP SILIWANGI BANDUNG
}

\begin{abstract}
ABSTRAK
Tujuan penelitian ini adalah untuk menelaah apakah peningkatan kemampuan komunikasi dan koneksi matematis mahasiswa calon guru yang belajar menggunakan pendekatan konstruktivisme dengan model pembelajaran generatif lebih baik dibandingkan dengan mahasiswa yang belajar dengan pembelajaran biasa, serta untuk mengetahui apakah terdapat hubungan antara kemampuan komunikasi dan koneksi matematis dengan self efficacy mahasiswa calon guru. Metode yang digunakan dalam penelitian ini adalah metode campuran antara kualitatif dan kuantitatif. Populasi dalam penelitian ini adalah seluruh mahasiswa calon guru di Kota Cimahi dan sampelnya adalah mahasiswa calon guru tingkat dua di STKIP Siliwangi Cimahi. Instrumen yang digunakan dalam penelitian ini berbentuk tes uraian koneksi dan komunikasi matematis, serta angket self-efficacy. Berdasarkan analisis data didapatkan kesimpulan bahwa peningkatan kemampuan komunikasi dan koneksi matematis mahasiswa calon guru yang belajar menggunakan pendekatan konstruktivisme dengan model pembelajaran generatif lebih baik dibandingkan dengan mahasiswa yang belajar dengan pembelajaran biasa, serta tidak terdapat hubungan antara kemampuan komunikasi dan koneksi matematis mahasiswa calon guru dengan self-efficacy mahasiswa calon guru.
\end{abstract}

Kata Kunci : Pendekatan Konstruktivisme, Model Pembelajaran Generatif, Komunikasi Matematis, Koneksi Matematis, Self Efficacy .

\begin{abstract}
Research Objectives is to review to examine whether the improved ability of Communication and Connection mathematically students Prospective teachers which studied using a constructivist approach with Learning Model generative better than to's student studying with ordinary learning, as well as for a review to know whether the relationship between the ability of Communication and Connection mathematical with Prospective student teacher self-efficacy. The method used is a method Singer Research hearts between mixture of qualitative and quantitative. Population Research was all students Prospective teachers in Cimahi And the sample is a student teacher candidates prayer rate in STKIP Siliwangi Cimahi. The instruments used Singer Research hearts shaped test mathematical description of connection and communication, as well as self-efficacy questionnaire. Based on analysis of data obtained conclusion that increase the ability of Communication and Connection mathematically students Prospective teachers Yang studied using a constructivist approach with Learning Model generative better than to's student studying with Learning plain, and there are currently no relation between ability Communications and Connections mathematically students Prospective teachers with Prospective student teachers themselves -efficacy.
\end{abstract}

Keywords : Constructivism approach, Generative Learning Model, Mathematical Communication, Connection Mathematically, Self Efficacy

\section{A. PENDAhuluan}

Seiring perkembangan ilmu pengetahuan, matematika memposisikan dirinya sebagai ilmu yang sangat berkontribusi terhadap peradaban manusia. Matematika adalah salah satu bagian yang penting dalam bidang ilmu pengetahuan. Dilihat dari sudut pengklasifikasian bidang ilmu pengetahuannya, matematika merupakan ilmu eksakta yang lebih banyak memerlukan pemahaman dari pada hapalan. Siswa harus mampu menguasai konsep-konsep pokok bahasan yang terkait, sehingga siswa dapat memahami suatu pokok bahasan dalam matematika untuk memecahkan masalah yang dihadapinya. Matematika dari bentuknya yang paling sederhana sampai dengan bentuknya yang kompleks memberikan sumbangan dalam pengembangan 
ilmu pengetahuan lainnya dan kehidupan seharihari, serta mengarahkan pada pemahaman konsep matematika yang diperlukan untuk menyelesaikan masalah matematika dan masalah ilmu pengetahuan lainnya serta memberikan kemampuan penalaran matematis siswa merupakan salah satu visi pembelajaran matematika (Sumarmo, 2005).

Salah satu dari tujuan pendidikan nasional yaitu mempersiapkan sumber daya manusia yang kreatif dan kompetitif dalam menghadapi era kemajuan pendidikan yang makin pesat. Guna tujuan pendidikan nasional tercapai, para penyelenggara pendidikan hendaknya memperhatikan prinsipprinsip penyelenggaraan pendidikan, sebagaimana tercantum dalam Undang-Undang Sisdiknas pasal 4 bab 3 mengenai prinsip penyelenggara pendidikan, yang salah satunya yaitu pengembangan dan peningkatkan potensi siswa, penyelenggara pendidikan di sekolah hendaknya berpegang pada prinsip bahwa pendidikan diselenggarakan sebagai suatu proses pembudayaan dan pemberdayaan peserta didik yang berlangsung sepanjang hayat, serta pendidikan diselenggarakan dengan memberi keteladanan, membangun kemauan, dan mengembangkan kreatifitas peserta didik dalam proses pembelajaran. Oleh sebab itu tentunya para calon guru yakni mahasiswa calon guru hendaknya dapat mempelajari prinsip penyelenggaraan pendidikan tersebut.

Sebagai calon guru dan juga calon pendidik dalam hal ini pelajaran matematika, hendaknya mahasiswa memiliki kemampuan untuk menyampaikan sesuatu yang diketahuinya memalui peristiwa dialog atau saling hubungan yang terjadi di lingkungan dalam hal ini kelas, dimana terjadi pengalihan pesan. Pesan yang dialiskan berisi mengenai materi-materi matematika yang dipelajari siswa, dapat berupa konsep, rumus, atau strategi penyelesaian suatu maslah. Kemampuan di atas termasuk ke dalam kemampuan komunikasi matematis. Melalui kemampuan komunikasi yang baik maka suatu masalah akan lebih cepat bisa direpresentasikan dengan benar dan hal ini akan mendukung untuk penyelesaian masalah sebab kemampuan komunikasi matematis menunjang kemampuankemampuan matematis yang lain, misalnya kemampuan pemecahan masalah. Hulukati (2005) menyatakan bahwa kemampuan komunikasi matematis merupakan syarat untuk memecahkan masalah, artinya jika siswa tidak dapat berkomunikasi dengan baik memaknai permasalahan maupun konsep matematika maka ia tidak dapat menyelesaikan masalah tersebut dengan baik.

Pelajaran matematika memuat beberapa kemampuan yang diharapkan dapat dikuasai siswa dan tentunya pula mahasiswa calon guru, salah satunya adalah kemampuan dalam melakukan koneksi matematis. Kemampuan koneksi matematis penting karena akan membantu penguasaan pemahaman konsep yang bermakna dan membantu untuk menyelesaikan masalah melalui keterkaitan antara konsep matematika dan antara konsep matematika dengan konsep dalam disiplin lain. Menurut Sumarmo (2012), kemampuan koneksi matematis ini akan membantu siswa dalam menyusun model matematika yang juga menggambarkan keterkaitan antar konsep danatau data suatu masalah atau situasi yang diberikan.

Koneksi matematis mengacu kepada pemahaman yang mengharuskan siswa dapat mernperlihatkan hubungan antara topik matematika. Sedangkan hubungan eksternal matematika meliputi hubungan antara matematika dengan bidang studi lain dan dengan kehidupan sehari-hari. Dalam pembelajaran matematika kemampuan menghubungkan suatu materi yang satu dengan materi yang lain atau dengan kehidupan sehari-hari berperan penting dalam proses pembelajaran dalam hal ini pembelajaran matematika. Melalui kemampuan koneksi matematis, kemampuan berfikir siswa terhadap matematika diharapkan dapat menjadi semakin luas. Selain itu, koneksi matematis dapat pula meningkatkan kemampuan kognitif siswa seperti mengingat kembali, memahami penerapan suatu konsep terhadap lingkungan dan sebagainya. Tanpa menerapkan konsep dengan pengalaman siswa, maka ia akan susah mengingat suatu materi yang disampaikan dan mengingat terlalu banyak konsep yang terpisah padahal matematika kaya akan prinsip-prinsip. Hal tersebut pun diungkapkan oleh Bruner (Russefendi, 2006) mengemukakan, "Dalam matematika setiap konsep itu berkaitan dengan konsep lain. Begitu pula antara yang lainnnya misalnya antara dalil dengan dalil, antara teori dan teori, antara topik denan topik, antara cabang matematika. Oleh karena itu, agar siswa berhasil belajar matematika, siswa harus lebih banyak diberi kesempatan untuk melihat kaitan-kaitan itu".

Berdasarkan uraian di atas tampak bahwa kemampuan komunikasi dan koneksi matematis penting dimiliki siswa. Akan tetapi selain kemampuan matematis tersebut mahasiswa calon 
guru hendak lah perlu juga memiliki perasaan yakin, persepsi, kepercayaan terhadap kemampuan mengatasi, mengorganisasi, melakukan suatu tugas, mencapai suatu tujuan, menghasilkan sesuatu dan mengimplementasi tindakan untuk menampilkan kecakapan pada suatu situasi tertentu yang nantinya akan berpengaruh pada cara individu mengatasi situasi tersebut atau dikenal juga dengan istilah self efficacy. Menurut Bandura (1995), self efficacy merupakan kepercayaan seseorang mengenai kemampuan dalam mengatur serta memutuskan suatu tindakan tertentu yang dibutuhkan untuk memperoleh suatu hasil.

Mahasiswa calon guru hendaklah dapat mengukur kemampuan dirinya, mampu mengusai beberapa bidang sekaligus untuk menyelesaikan suatu tugas, memiliki tekad untuk melakukan usaha yang keras, walaupun menemui hambatan. Tetapi kemampuan tersebut tentulah melalui proses, dan proses self efficacy tersebut meliputi proses kognitif, proses motivasi, proses afeksi, dan proses seleksi. Kata lain yang lebih singkat mengenai Self efficacy berkaitan dengan kepercayaan akan kemampuan diri, keyakinan diri, atau Sandtrock (Rahmawati, 2012) mengatakan dengan kata lainnya "Aku bisa". Keyakinan akan diri tersebut akan mempengaruhi pola pikir dan tindakan - tindakan yang akan dilakukan selanjutnya dalam menyelesaikan permasalahan.

Self efficacy sangat mengutamakan penguasaan diri di dalam aspek kemampuan kognitif agar menghasilkan performa yang baik sehingga dapat mencapai tujuan dengan baik. Tetapi dari berbagai hasil penelitian dikemukakan bahwa self efficacy tidak akan muncul dengan sendirinya, (Setiadi, 2010) ia dipengaruhi oleh berbagai faktor lainnya yang saling berkaitan seperti latihan, sumber mengajar, dan dukungan serta self efficacy guru berkorelasi dengan peranan guru didalam keberhasilan dan kegagan siswa di dalam kemampuan akademik, self efficacy guru berkorelasi dengan keyakinan penguasaan kelas serta di dalam memberikan penilaian.

Pendekatan kostruktivisme merupakan suatu pendekatan yang bersifat membangun pengetahuan peserta didik dengan mengaitkan ilmu yang sudah ada pada peserta didik dengan ilmu yang baru dalam pembelajaran yang aktif untuk menemukan pengetahuan mereka sendiri. Seperti yang dikemukakan oleh Nurhadi (2003:33), pendekatan konstruktivisme merupakan suatu pendekatan dimana peserta didik harus mampu menemukan dan mentransformasikan suatu infomasi komplek ke situasi lain, apabila dikehendaki informasi itu menjadi milik mereka sendiri. Dalam proses pembelajaran peserta didik membangun sendiri pengetahuan mereka melalui keterlibatan aktif dalam pembelajaran dan peserta didik menjadi pusat kegiatan. Pengetahuan bukanlah seperangkat fakta-fakta, konsep, atau kaidah yang siap untuk diambil dan diingat. Manusia harus mengonstruksi pengetahuan itu dan memberi makna melalui pengalaman nyata. Peserta didik perlu dibiasakan untuk memecahkan masalah, menemukan sesuatu yang berguna bagi dirinya, dan bergelut dengan ide-ide.

Selain pendekatan konstruktivisme, peneliti tertarik untuk menggabungkannya dengan model pembelajara generatif guna meningkatkan kemampuan komunikasi dan koneksi mahasiswa, sebab model pembelajaran generatif merupakan suatu model pembelajaran berbasis konstruktivisme, yang lebih menekankan pada pengintegrasian secara aktif pengetahuan baru dengan menggunakan pengetahuan yang sudah dimiliki siswa sebelumnya. Langkah-langkah yang terdapat dalam model pembelajaran generatif memungkian siswa untuk belajar lebih aktif dalam mengkonstruksi pengetahuannya, melalui lima tahapan, yaitu orientasi, pengungkapan ide, tantangan dan restrukturisasi, penerapan dan pengevaluasian. Tahapan-tahapan dalam pembelajaran generatif ini menuntut siswa dalam hal ini mahasiswa untuk aktif dalam membentuk pengetahuannya. Melalui pembelajaran generatif diharapkan dapat terciptanya suatu iklim belajar, mahasiswa mendapat kebebasan dalam mengajukan ide-ide, pertanyaan-pertanyaan dan masalah-masalah sehingga belajar matematika lebih efektif dan bermakna. Melaui model pembelajaran generatif dapat membatu guru (Hulukati, 2005), karena guru dapat: (1)memahami cara berfikir siswa; (2)membantu memodifikasi jawaban siswa; (3)mengetahui dari mana dan bagaimana siswa dapat menemukan jawaban tersebut.

Berdasarkan uraian di atas, sangat jelas terlihat bahwa kemampuan koneksi, kemampuan komunikasi, dan self efficacy memiliki kaitan di dalam kegiatan pembelajaran mahasiswa. Sehingga peneliti tertarik untuk mengkaji apakah terdapat hubungan antara kemampuan komunikasi dan koneksi matematis siswa terhadap self efficacy-nya dengan menggunakan pendekatan konstruktivisme melalui model pembelajaran generatif. Berdasarkan uraian di atas peneliti tertarik untuk membahas mengenai, "Pendekatan 
Konstruktivisme dengan Model Pembelajaran Generatif Guna Meningkatkan Kemampuan Komunikasi dan Koneksi Matematis serta Self Efficacy Mahasiswa Calon Guru Di Kota Cimahi”. Berdasarkan latar belakang masalah di atas, maka rumusan masalahnya adalah:

1) Apakah peningkatan kemampuan komunikasi matematis mahasiswa calon guru yang pembelajarannya menggunakan pendekatan konstruktivisme dengan model generatif lebih baik dari pada yang menggunakan pembelajaran biasa?

2) Apakah peningkatan kemampuan koneksi matematis mahasiswa calon guru yang pembelajarannya menggunakan pendekatan konstruktivisme dengan model generatif lebih baik dari pada yang menggunakan pembelajaran biasa?

3) Apakah terdapat hubungan yang positif antara kemampuan komunikasi matematis dengan self efficacy mahasiswa calon guru?

4) Apakah terdapat hubungan yang positif antara kemampuan koneksi matematis dengan self efficacy mahasiswa calon guru?

\section{B. LANDASAN TEORI}

\section{Kemampuan Komunikasi Matematis}

Komunikasi berasal dari bahasa Inggris yaitu communicate yang berarti menceritakan, menyampaikan. Di dalam dunia pendidikan matematika, komunikasi matematika menurut Ontario Ministry of Education (dalam Son, 2015) mengatakan bahwa proses mengekspresikan ideide dan pemahaman matematika secara lisan, visual, dan tertulis, menggunakan angka, simbol, gambar, grafik, diagram, dan kata-kata. Komunikasi adalah proses penyampaian makna dalam bentuk gagasan atau informasi dari seseorang kepada orang lain yang dapat dilakukan dengan berbagai media atau perantara ataupun bisa secara langsung tanpa adanya perantara atau media dengan kondisi antara pemberi dan penerima memahami media atau perantara yang digunakan (Son, 2015). Dalam kegiatan belajar matematika, Viseu dan Oliveria (Son, 2015: 4) mengemukakan bahwa komunikasi dapat merangsang siswa di dalam berbagi ide, pikiran, dugaan dan solusi matemmatika. Belajar matematika saat ini tidak hanya mengutamakan pada jawaban yang benar saja, tetapi bagaimana proses di dalam menemukan jawaban tersebut, bagaimana cara dalam mengkomunikasikan ide di dalam penyelesaian masalah.
Indikator komunikasi matematis yang sering digunakan di dalam dunia pendidikan adalah Indikator komunikasi matematika dalam Sumarmo (2010: 4) adalah sebagai berikut. (1)Menghubungkan benda nyata, gambar, dan diagram ke dalam ide matematika; (2)Menjelaskan ide, situasi, dan relasi matematika secara lisan atau tulisan, dengan benda nyata, gambar, grafik, dan aljabar; (3)Menyatakan peristiwa sehari-hari dalam bahasa/simbol matematika; (4)Mendengarkan, berdiskusi, dan menulis tentang matematika; (5)Membaca presentasi matematika evaluasi dan menyusun pertanyaan yang relevan; (6)Menyusun argumen, merumuskan definisi, dan generalisasi.

Adapun kemampuan komunikasi yang diukur dalam penelitian ini adalah Kemampuan Komunikasi matematis adalah mampu: (1) mempresentasikan atau melukiskan benda nyata, gambar dan diagram dalam bentuk ide dan atau simbol matematika, (2) menjelaskan ide, situasi dan relasi matematik, secara lisan dan tulisan dengan menggunakan benda nyata, gambar, grafik dan ekspresi aljabar.

\section{Kemampuan Koneksi Matematis}

Koneksi berasal dari kata connection yang berarti hubungan atau kaitan. Sedangkan koneksi matematis adalah dua kata yang berbeda yaitu mathematical connection, yang kemudian dipopulerkan oleh NCTM yang selanjutnya dijadikan standar kurikulum. Terdapat dua tipe khusus koneksi matematis menurut NCTM (1989: 146), yaitu modeling connections dan mathematical connections. Modeling connections merupakan hubungan antara situasi masalah yang muncul di dalam dunia nyata atau disiplin ilmuyang lain dengan representasi matematisnya, sedangkan mathematical connections adalah hubungan antara dua representasi yang ekuivalen, dan antara proses penyelesaian dari masing-masing representasi.

Bruney dan Keney (dalam Fauzi, 2011, 44) mengatakan bahwa kaidah koneksi setiap konsep, prinsip, dan keterampilan dalam matematika dikoneksikan dengan konsep, prinsip, dan keterampilan lainnya. Sumarmo (2010: 6) mengemukakan bahwa koneksi matematis disusun dalam indikator-indikator, yaitu: (1) Mencari hubungan berbagai representasi konsepdan prosedur; (2) Memahami hubungan atar topik matematika; (3) Menggunakan matematikadalam bidang studi lain atau kehidupan sehari-hari;

Memahami representasi ekivalen konsep atau prosedur yang sama; (4) Mencari koneksi satu 
prosedur ke prosedur lain dalam representasi yang ekivalen; (5) Menggunakan koneksi antar topik matematika, dan antara topik matematika dengan topik lain.

Kemampuan koneksi matematis akan berkorelasi dengan kemampuan-kemampuan lainnya yang tidak dapat dipisahkan. Secara tidak langsung mahasiswa harus sudah memliki kemampuan koneksi yang baik. Dewi (2013) kemampuan koneksi matematis diperlukan mahasiswa karena matematika merupakan satu kesatuan, di mana konsep yang satu berhubungan dengan konsep yang lain. Atau dengan perkataan lain untuk mempelajari suatu konsep tertentu dalam matematika diperlukan prasarat dari konsepkonsep yang lain. Oleh karena itu agar mahasiswa calon guru harus lebih banyak melakukan latihanlatihan agar dapat meningkatkan kemampuan koneksi matematis. Konsep matematika harus kuat didalam diri mahasiswa calon guru, karena kelak ia akan menyampaina pengetahuan tersebut kepada peserta didik. Dewi (2013), apabila mahasiswa mampu mengkaitkan ide-ide matematika maka pemahaman matematikanya akan semakin dalam dan bertahan lama karena mereka mampu melihat keterkaitan antar topik dalam matematika, dengan konteks selain matematika, dan dengan pengalaman hidup sehari-hari.

Kemampuan koneksi yang diukur dalam penelitian ini adalah kemampuan di dalam : (1) engaitkan konsep-konsep matematika baik antar konsep matematika itu sendiri (dalam matematika), (2)mengaitkan konsep matematika dengan bidang lainnya (luar matematika), yang meliputi: koneksi antar topik matematika, koneksi dengan disiplin ilmu lain, dan (3)koneksi dengan kehidupan seharihari.

\section{Self - Efficacy}

Self-efficacy merupakan keyakinan akan kemampuan diri di dalam mengorganisir pikirannya sehingga menghasilkan hasil yang baik. Menurut Bandura (1995), Self-efficacy didefinisikan sebagai keyakinan yang ada di dalam diri mengenai kemampuan mereka di dalam menunjukkan dan melakukan kegiatan. Karakteristik self-efficacy yang khas menurut Eisenberger, Conti-D'Antonio, Bertrando (Setiadi, 2010) yaitu : (1) mengetahui kemampuan diri, (2) pengendalian kemampuan dan pengetahuan, (3) disiplin diri, (4) mengutamakan penampilan, (5) memprediksi usaha dan motivasi, (6) hasil dari refleksi, dan (7) menghasilkan prestasi.
Self-efficacy bukanlah merupakan suatu keyakinan yang umum tentang diri sendiri, tetapi merupakan sebuah keyakinan khusus yang mengarah pada suatu tujuan tertentu. Self -efficacy menunjuk pada keyakinan akan kemampuannya untuk meggerakkan motivasi, sumber-sumber kognitif dan serangkaian tindakan yang diperlukan untuk menghadapi tuntutan situasi (Handayani, 2011: 25). Dari beberapa pandangan mengenai selfefficacy, dapat dikatakan bahwa self-efficacy sebenarnya mengarah pada "kepercayaaan dan kemampuan diri” untuk mengkoordinir, melaksanakan, dan mendapatkan hasil sesuai dengan yang diharapkan. Ketika seseorang memiliki self-efficacy yang baik,ia akan dapat meminimalisir dari berbagai bentuk kesalahan karena ia akan memikirkan dan merencanakan apa saja yang akan dilakukannya. Sehingga dapat dikatakan bahwa salah satu penunjang keberhasilan ialah dengan memiliki self-efficacy yang baik.

Bandura (Setiadi, 2010: 30) mengungkapkan beberapa hal yang sangat penting yang berkontribusi terhadap self-efficacy antara lain: (1) Mastery Experience, (2) Vicarious experience, (3) Verbal persuasion and other related social influences, (4) Physiological and affective states. Mastery Experience merupakan pengalaman otentik yang di dapatkan oleh individu sendiri, diamana ia akan merefleksi hal-hal yang membuat ia gagal ataupun berhasil. Bandura (Setiadi, 2010) mengungkapkan faktor-faktor yang mempengaruhi pengalaman otentik yaitu: (1) prasangka terhadap kemampuan diri, (2) cara menerima dan menghadapi kesulitan, (3) usaha untuk mendapatkan kemampuan, (4) pengaruh dari orang lain, (5) cara di dalam bertindak, (6) waktu dimana ketika menghadapi kegagalan dan kesuksesan, (7) cara individu di dalam mengatur pengalaman diri nya termasuk didalam proses kemampuan kognitif. Vicarious experience merupakan bagaimana cara seseorang belajar dari diri sendiri ataupun orang lain. Untuk mendapatkan pengalaman ini, seseorang akan menjidakan orang lain sebagai model untuk dirinya sendiri yang kemudian akan dicontoh dan di ikuti (Setiadi, 2010). Verbal persuasion and other related social influences merupakan feedback yang diberikan oleh orang lain atas apa yang telah kita lakukan baik itu positif ataupun negative (Setiadi, 2010). Physiological and affective states merupakan aspek psikologi atau emosi. Bandura (Setiadi, 2010) mengatakan bahwa psikologi berkaitan erat dengan tingkah laku, bagaimana ia 
bertingkah baik atau buruk akan sesuai dengan tingkat emosinya.

\section{Pendekatan Konstruktivisme}

Konstruktivisme sebenarnya bukan merupakan gagasan yang baru, apa yang dilalui dalam kehidupan kita selama ini merupakan himpunan dan pembinaan pengalaman demi pengalaman. Ini menyebabkan seseorang mempunyai pengetahuan dan menjadi lebih dinamis.

Piaget mengemukakan bahwa pengetahuan tidak diperoleh secara pasif oleh seseorang, melainkan melalui tindakan. Bahkan, perkembangan kognitif anak bergantung pada seberapa jauh mereka aktif memanipulasi dan berinteraksi dengan lingkungannya. Sedangkan, perkembangan kognitif itu sendiri merupakan proses berkesinambungan tentang keadaan ketidakseimbangan dan keadaan keseimbangan (Poedjiadi, 1999: 61).

Pandangan tentang anak dari kalangan konstruktivistik yang lebih mutakhir yang dikembangkan dari teori belajar kognitif Piaget menyatakan bahwa ilmu pengetahuan dibangun dalam pikiran seorang anak dengan kegiatan asimilasi dan akomodasi sesuai dengan skemata yang dimilikinya. Belajar merupakan proses aktif untuk mengembangkan skemata sehingga pengetahuan terkait bagaikan jaring laba-laba dan bukan sekedar tersusun secara hirarkis (Hudoyo, 1998: 5).

Dari pengertian di atas, dapat dipahami bahwa belajar adalah suatu aktivitas yang berlangsung secara interaktif antara faktor intern pada diri pebelajar dengan faktor ekstern atau lingkungan, sehingga melahirkan perubahan tingkah laku. Wheatley (1991: 12) mendukung pendapat di atas dengan mengajukan dua prinsip utama dalam pembelajaran dengan teori belajar konstrukltivisme. Pertama, pengetahuan tidak dapat diperoleh secara pasif, tetapi secara aktif oleh struktur kognitif siswa. Kedua, fungsi kognisi bersifat adaptif dan membantu pengorganisasian melalui pengalaman nyata yang dimiliki anak.

Selain penekanan dan tahap-tahap tertentu yang perlu diperhatikan dalam teori belajar konstruktivisme, Hanbury (1996: 3) mengemukakan sejumlah aspek dalam kaitannya dengan pembelajaran matematika, yaitu (1) siswa mengkonstruksi pengetahuan matematika dengan cara mengintegrasikan ide yang mereka miliki, (2) matematika menjadi lebih bermakna karena siswa mengerti, (3) strategi siswa lebih bernilai, dan (4) siswa mempunyai kesempatan untuk berdiskusi dan saling bertukar pengalaman dan ilmu pengetahuan dengan temannya.

Dalam upaya mengimplementasikan teori belajar konstruktivisme, Tytler (1996: 20) mengajukan beberapa saran yang berkaitan dengan rancangan pembelajaran, sebagai berikut: (1) memberi kesempatan kepada siswa untuk mengemukakan gagasannya dengan bahasa sendiri, (2) memberi kesempatan kepada siswa untuk berfikir tentang pengalamannya sehingga menjadi lebih kreatif dan imajinatif, (3) memberi kesempatan kepada siswa untuk mencoba gagasan baru, (4) memberi pengalaman yang berhubungan dengan gagasan yang telah dimiliki siswa, (5) mendorong siswa untuk memikirkan perubahan gagasan mereka, dan (6) menciptakan lingkungan belajar yang kondusif. Dari beberapa pandangan di atas, dapat disimpulkan bahwa pembelajaran yang mengacu kepada teori belajar konstruktivisme lebih menfokuskan pada kesuksesan siswa dalam mengorganisasikan pengalaman mereka. Bukan kepatuhan siswa dalam refleksi atas apa yang telah diperintahkan dan dilakukan oleh guru. Dengan kata lain, siswa lebih diutamakan untuk mengkonstruksi sendiri pengetahuan mereka melalui asimilasi dan akomodasi.

\section{Model Pembelajaran Generatif (Generative Learning)}

Model pembelajaran generatif adalah salah satu model pembelajaran yang berlandaskan pada pandangan konstruktivisme, dengan asumsi dasar bahwa pengetahuan dibangun dalam pikiran siswa. Model pembelajaran generatif dikembangkan pada tahun 1985 oleh Osborne dan Wittrock (Hulukati, 2005). Wittrock (1992) menyatakan bahwa model pembelajaran generatif merupakan suatu model pembelajaran tentang bagaimana seorang siswa membangun pengetahuan dalam pikirannya, seperti membangun ide tentang suatu fenomena atau membangun arti suatu istilah dan juga membangun strategi untuk sampai pada suatu penjelasan tentang pertanyaan bagaimana dan mengapa. Wittrock (Grabowski, 2001:720) mengonsepkan model pembelajaran generatif berdasarkan model neural dari fungsi otak dan telaah kognitif pada proses pengetahuan. Hal ini ditegaskan Osborne dan Wittrock (Hulukati, 2005) bahwa intisari dari pembelajaran generatif adalah otak tidak menerima informasi dengan pasif, melainkan justru dengan aktif mengkonstruksi suatu interpretasi dari informasi tersebut dan kemudian membuat kesimpulan. Otak bukanlah 
suatu 'blank slate' yang dengan pasif belajar dan mencatat semua informasi yang diberikan.

Penerapan model pembelajaran generatif merupakan suatu cara yang baik untuk mengetahui pola pikir siswa serta bagaimana siswa memahami dan memecahkan masalah dengan baik. Secara ringkasnya model pembelajaran generatif adalah suatu model pembelajaran berdasarkan kepada penyelidikan tentang bagaimana manusia belajar. Sejalan dengan itu Jonasse (Marrison, 2011) mengemukakan bahwa strategi pembelajaran generatif, "are those that require learners consciously and deliberately to relate new information to existing knowledge". Dengan demikian melalui model pembelajaran generatif, pengetahuan yang dimiliki oleh siswa adalah hasil daripada aktivitas yang dilakukan oleh pelajar tersebut dan bukan pengajaran yang diterima secara pasif.

Tahap orientasi, merupakan tahap memotivasi siswa untuk mempelajari materi yang akan diajarkan dengan mengaitkan manfaat materi tersebut di dalam kehidupan sehari-hari. Siswa diberikan kesempatan untuk membangun kesan mengenai konsep yang sedang dipelajari dengan menghubungkannya dengan pengalaman seharihari (Osborne dan Wittrock dalam Hulukati, 2005). Tujuannya agar dalam proses pembelajaran siswa dapat membayangkan sesuatu serta dapat memanfaatkan pengalaman dan pengetahuan yang telah dimilikinya untuk menyelesaikan masalah pada pokok bahasan yang sedang dihadapi, dengan demikian siswa termotivasi mempelajari pokok bahasan yang akan dipelajari.

Dalam tahap pengungkapan ide, Osborne dan Wittrock (Hulukati, 2005) menjelaskan bahwa pada tahap ini guru dapat mengetahui ide atau konsep awal yang dimiliki siswa mengenai materi yang akan diajarkan. Siswa diberikan kesempatan untuk mengemukakan ide mereka mengenai konsep yang dipelajari. Guru berperan sebagai motivator dengan cara mengajukan pertanyaan yang bersifat menggali pengetahuan siswa (Socratic questioning) sehingga akan terungkap ide atau gagasan yang ada dalam benak siswa. Pertanyaan yang bersifat menggali dapat membantu siswa menghargai kekurangajegan cara berpikir mereka dan mengkontruksi kembali gagasan mereka dengan cara yang lebih koheren atau bertalian secara logis. Grabowski (2001:723) mengatakan, "Teaching and design strategies that deal with attribution should result in enduring interest, persistence, and motivation".
Setelah fase eksplorasi, fase selajutnya menurut Tytler (Fitriandini, 2009) adalah fase pemusatan (focus), pada fase ini guru melakukan pemusatan yang terarah pada konsep yang akan dipelajari oleh siswa. Kemudian siswa melakukan kegiatan untuk mengenal materi-materi yang digunakan untuk mengajukan pertanyaan (masalah atau soal). Pada saat itu siswa diharapkan untuk mengajukan pertanyaan-pertanyaan yang berkaitan dengan topik yang dipelajari, selanjutnya respon siswa diinterpretasikan dan diklarifikasi. Selain itu juga siswa dapat mengajukan pertanyaan-pertanyaan mengenai konsep yang dipelajari, melakukan refleksi dan mengklarifikasi konsepnya apa benar atau tidak. Selanjutnya para siswa mengkomunikasikan pada temannya melalui diskusi kelas atau diskusi kelompok.

Tahap Tantangan dan Restrukturisasi, pada tahap ini guru memunculkan cognitive conflict dengan cara menyiapkan kondisi dimana siswa diminta membandingkan pendapatnya dengan pendapat temannya, serta bisa mengupayakan mengungkapkan kebenaran/keunggulan pendapatnya. Kemudian guru mengusulkan peragaan atau demonstrasi untuk menguji kebenaran pendapat mereka (Osborne dan Wittrock dalam Hulukati, 2005).

Diharapkan selama proses ini muncul konflik antara apa yang dimiliki siswa dengan apa yang dilihat dan diperagakan oleh guru. Grobowski (2001) mengemukakan, "External stimuli arouse attention through the ascending reticular activating system. Without active, dynamic, and selective attending of an environmental stimulus, it follows that meaning generation cannot occur regarding that environmental stimulus." Setelah tahap tantangan tersebut diharapkan siswa bisa memperoleh pemahaman baru yang lebih benar mengenai konsep yang bersangkutan. Supaya siswa mempunyai keinginan untuk mengubah struktur pemahaman mereka, siswa diberikan masalah-masalah yang menantang untuk membangkitkan keberaniannya dalam mengajukan pandapatnya dan berargumentasi tentang pokok bahasan yang sedang dipelajari.

Tahap selanjutnya dalam pembelajaran generatif menurut Osborne dan Wittrock (Hulukati, 2005) adalah tahap penerapan, pada tahap ini siswa menerapkan konsep awal yang mereka miliki ditambah konsep baru yang mereka peroleh pada permasalahan matematika dalam bentuk latihanlatihan soal. Siswa diberikan kesempatan untuk memecahkan masalah yang lebih kompleks, 
menguji ide alternatif yang mereka bangun untuk menyelesaikan persoalan yang bervariasi. Kegiatan siswa dalam fase terakhir ini antara lain adalah memecahkan soal-soal praktis berdasarkan konsepkonsep yang benar, menyajikan solusi dari suatu masalah kepada teman sejawatnya, berdiskusi dan beradu argumentasi tentang konsep-konsep yang benar, dan secara kritis mengevaluasi penggunaan konsep-konsep itu adalah situasi yang berbeda. Pada fase ini siswa mengevaluasi dan membandingkan antara pengetahuan tentang konsep-konsep sebelumnya dengan konsep yang telah dikontruksi, dan mengadakan refleksi terhadap prosedur yang ditempuh. Selanjutnya guru mengadakan review terhadap perubahanperubahan ide-ide siswa sebagai hasil restrukturisasi terhadap gagasan atau ide awalnya.

Tahap terakhir menurut Osborne dan Wittrock (Hulukati, 2005) adalah tahap melihat kembali. Siswa diberi kesempatan untuk mengevaluasi kelemahan dari konsep yang dimilikinya, kemudian memilih cara/konsep yang paling efektif dalam menyelesaikan permasalahan. Siswa juga diharapkan dapat mengingat kembali konsep yang sudah dipelajari secara keseluruhan. Kondisi ini memberikan peluang kepada siswa untuk mengungkap tentang apa yang sudah dan sedang dikerjakannya. Apakah yang dikerjakannya itu sudah sesuai dengan apa yang dipikirkannya.

Dalam belajar generatif siswa sendirilah yang aktif membangun pengetahuannya, sedangkan guru berperan sebagai fasilitator dan mediator dalam pembelajaran. Model pembelajaran generatif berbasis pada pandangan konstruktivisme, dengan asumsi dasar bahwa pengetahuan dibangun dalam pikiran siswa.

Grabowski (2001) mengatakan bahwa model pembelajaran generatif bukan model pembelajaran penemuan (discovery learning) tetapi pembelajaran yang berpusat pada siswa (student-centric learning) dengan siswa secara aktif membangun makna dari pembelajaran. Wittrock (1992) mengemukakan, "This functional model of generative learning leads to the design of effective instructional procedures that often produce sizable gains in comprehension and understanding." Jadi model pembelajaran generatif diharapkan dapat menarik perhatian siswa untuk secara aktif meningkatkan pemahamannya terhadap materi pembelajaran.

Hipotesis Penelitian

1) Peningkatan kemampuan komunikasi matematis mahasiswa calon guru yang pembelajarannya menggunakan pendekatan konstruktivisme dengan model generatif lebih baik dari pada yang menggunakan pembelajaran biasa.

2) Peningkatan kemampuan koneksi matematis mahasiswa calon guru yang pembelajarannya menggunakan pendekatan konstruktivisme dengan model generatif lebih baik dari pada yang menggunakan pembelajaran biasa.

3) Terdapat hubungan yang positif antara kemampuan komunikasi matematis dengan self efficacy mahasiswa calon guru.

4) Terdapat hubungan yang positif antara kemampuan koneksi matematis dengan self efficacy mahasiswa calon guru.

\section{METODE DAN DESAIN PENELITIAN}

Penelitian ini merupakan penelitian kuasi eksperimen karena adanya keterbatasan hal mengkontrol factor-faktor yang kemungkinan dapat mengintervensi situasi pembelajaran yang dilakukan. Disain eksperimen yang digunakan adalah disain kelompok kontrol non-ekuivalen sebagai berikut:

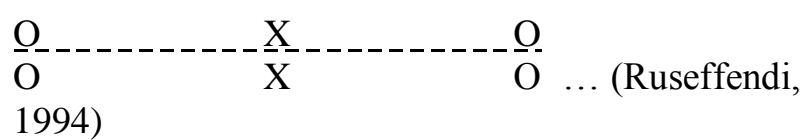

Keterangan:

$\mathrm{O}=$ Pretes $=$ Postes kemampuan komunikasi dan koneksi matematis

$\mathrm{X}=$ Pendekatan kontruktivisme dengan model pembelajaran Generatif

Penelitian ini akan dilaksanakan di salah satu STKIP di kota cimahi. Penelitian ini akan dilaksanakan pada bulan Maret hingga bulan Agustus tahun 2016. Populasi dari penelitian ini adalah mahasiswa calon guru di Kota Cimahi. Dari seluruh mahasiswa tersebut dipilih secara acak untuk dijadikan sampel dari penelitian ini.

Instrumen dari penelitian ini adalah seperangkat soal tes kemampuan komunikasi matematis, kemampuan koneksi matematis, dan angket selfefficacy. Instrument di dalam hal ini adalah untuk mengukur kemampuan komunikasi matematis, koneksi matematis, dan self-efficacy. Sebelum instrumen tersebut dijadikan instrumen penelitian, instrumen tersebut terlebih dahulu diukur face validity, content validity, dan construct validity oleh ahli (expert) yaitu dosen senior dan sesama rekan peneliti dan dosen muda. Instrumen terdiri dari tiga soal kemampuan komunikasi dan tiga soal kemampuan koneksi matematis, serta 15 butir pernyataan di dalam angket self-efficacy. Berikut 
hasil analisis uji coba kemampuan komunikasi dan koneksi matematis mahasiswa calon guru.

Tabel 1

Rekapitulasi Uji Coba Instrumen Kemampuan Komunikasi dan Koneksi Matematis

\begin{tabular}{|c|c|c|c|c|c|}
\hline $\begin{array}{l}\text { N } \\
\text { o. } \\
\text { So } \\
\text { al }\end{array}$ & $\begin{array}{c}\text { Valid } \\
\text { itas }\end{array}$ & $\begin{array}{c}\text { Reliabi } \\
\text { litas }\end{array}$ & $\begin{array}{c}\text { Daya } \\
\text { Pemb } \\
\text { eda }\end{array}$ & $\begin{array}{c}\text { Indeks } \\
\text { Kesuk } \\
\text { aran }\end{array}$ & $\begin{array}{c}\text { Kesimp } \\
\text { ulan }\end{array}$ \\
\hline 1 & 0,55 & \multirow{6}{*}{0,60} & 0,29 & 0,85 & Dipakai \\
\hline 2 & 0,61 & & 0,25 & 0,86 & Dipakai \\
\hline 3 & 0,42 & & 0,39 & 0,72 & Dipakai \\
\hline 4 & 0,65 & & 0,39 & 0,87 & Dipakai \\
\hline 5 & 0,49 & & 0,36 & 0,80 & Dipakai \\
\hline 6 & 0,62 & & 0,29 & 0,75 & Dipakai \\
\hline
\end{tabular}

Berdasarkan Tabel 1 yaitu rekapitulasi uji coba instrumen kemampuan komunikasi dan koneksi matematis mahasiswa calon guru dari 6 soal ratarata memiliki validitas sedang, memiliki reliabilitas yang tinggi, daya pembeda cukup dan indeks kesukaran yang rata - rata mudah. Berdasarkan hasil rekapitulasi tersebut, maka dari ke-6 soal tersebut diambil seluruh soal untuk dijadikan soal pretes dan postes kemampuan komunikasi dan koneksi matematis mahasiswa calon guru.

\section{ANALISIS DAN PEMBEHASAN}

\section{a. Analisis Data}

Penelitian Penelitian ini bertujuan untuk mengetahui peningkatan kemampuan komunikasi dan koneksi matematis mahasiswa calon guru yang belajar menggunakan pendekatan konstruktivisme dengan model pembelajaran generatif. Analisis data yang dilakukan yaitu dengan menganalisis data pretes kemampuan komunikasi dan koneksi matematis mahasiswa calon guru untuk menelaah kemampuan awal komunikasi dan koneksi matematis mahasiswa calon guru sebelum mendapatkan pembelajaran. Kemudian data $\mathrm{N}$-gain untuk mengetahui peningkatan kemampuan komunikasi dan koneksi matematis mahasiswa calon guru. Untuk mengetahui hubungan antara kemampuan komunikasi dan koneksi matematis mahasiswa calon guru dengan self-efficacy mahasiswa calon guru yaitu dengan menganalisis data angket akhir self-efficacy dan data postes kemapuan komunikasi dan koneksi mahasiswa calon guru. Pengolahan data dilakukan dengan menggunakan bantuan progran Microsoft Office Excel 2010 dan SPSS 16. Berikut ini akan diuraikan hasil penelitian dan pembahasannya.
Pengolahan data tes kemampuan komunikasi dan koneksi matematis mahasiswa calon guru berdasarkan pada skor pretes, postes, dan $\mathrm{N}$-gain. Sedangkan untuk angket self-efficacy mahasiswa calon guru berdasarkan pada Berdasarkan data yang diperoleh, yaitu data pretes, postes, dan $\mathrm{N}$ gain kemampuan komunikasi serta koneksi matematis mahasiswa calon guru serta data angket akhir self-efficacy mahasiswa calon guru.

Tabel 2

Deskriptif Statistik Kemampuan Komunikasi dan Koneksi Matematis

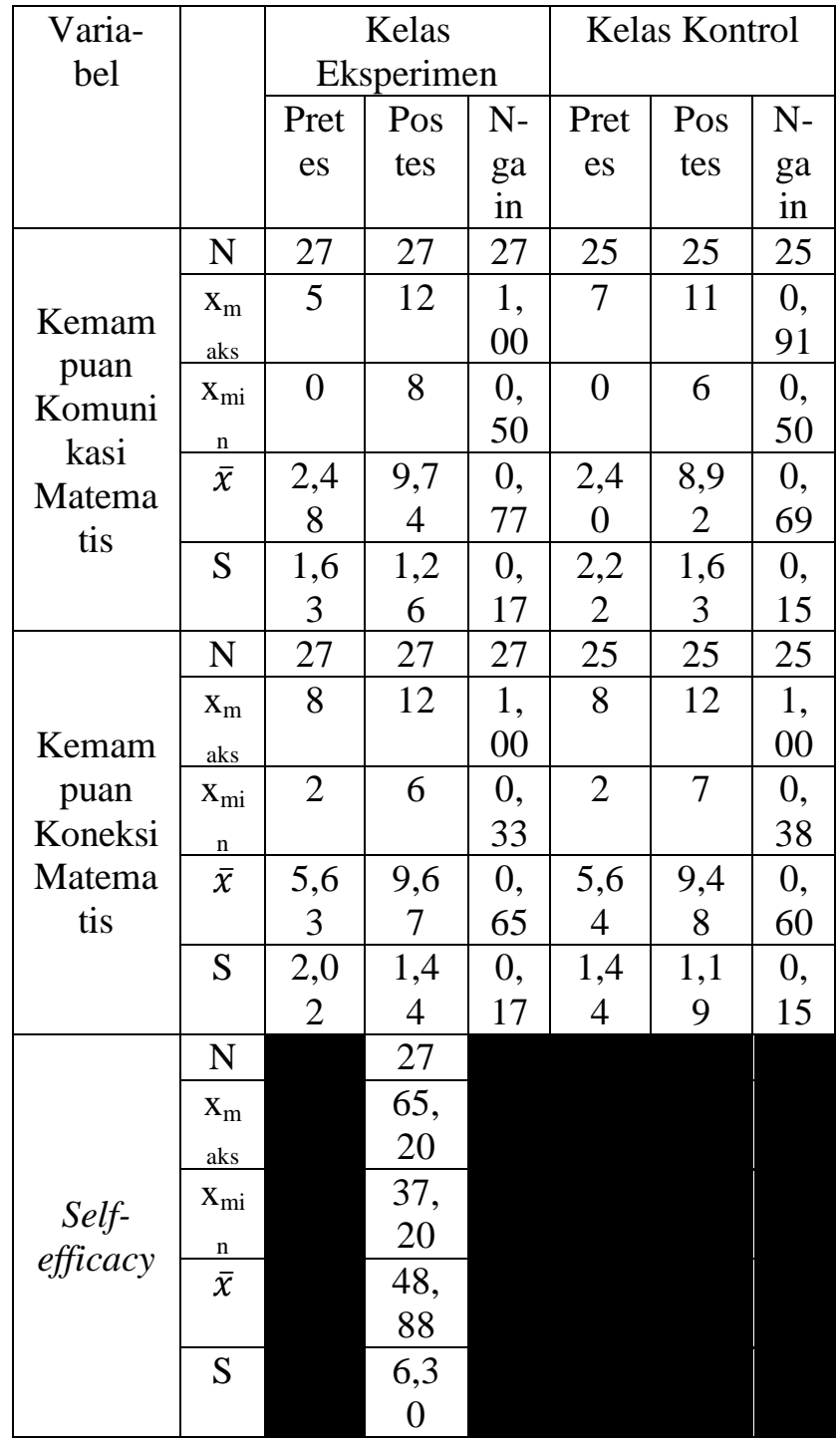

SMI Kemampuan Komunikasi dan Koneksi Mmatematis : 12

SMI Self-efficacy : 70,8

\section{Analisis Peningkatan Kemampuan Komunukasi Matematis}

Untuk mengetahui peningkatan kemampuan komunikasi matematis mahasiswa calon guru yang belajar menggunakan pendekatan konstruktivisme dengan model pembelajaran generatif dilakukan 
beberapa tahapan uji statistik pada data pretes dan $\mathrm{N}$-gain kemampuan komunikasi matematis. Untuk mengetahui signifikansi kesamaan dua rerata skor pretes kemampuan komunikasi mahasiswa calon guru maka dilakukan uji kesamaan dua rerata, yaitu dengan tahapan uji normalitas, uji homogenitas dan uji kesamaan dua rerata.

\section{Tabel 3}

Hasil Uji Normalitas Pretes Kemampuan Komunikasi Matematis

\begin{tabular}{|l|r|r|r|}
\hline \multirow{2}{*}{} & \multicolumn{3}{|c|}{ Shapiro-Wilk } \\
\cline { 2 - 4 } & Statistic & \multicolumn{1}{c|}{ Df } & \multicolumn{1}{c|}{ Sig. } \\
\hline pretes & .913 & 25 & .03 \\
\hline pretes & .888 & 25 & .010 \\
\hline
\end{tabular}

Berdasarkan Tabel 3 didapatkan nilai sig. sebesar 0,035 dan 0,010 pada skoor pretes kelas eksperimen dan kontrol. Karena sig $<0,05$ untuk kelas eksperimen dan kontrol, maka dapat disimpulkan bahwa kedua kelas tidak berdistribusi normal. Karena kedua kelas tidak berdistribusi normal, maka dilanjutkan dengan uji non parametrik Mann Whitney.

Tabel 4

\section{Hasil Uji Mann Whitney Pretes Kemampuan} Komunikasi Matematis

\begin{tabular}{|l|c|}
\hline & $\begin{array}{c}\text { pretes } \\
\text { komunikasi eks } \\
\text { dan kon }\end{array}$ \\
\hline Mann-Whitney U & 307.500 \\
\hline Wilcoxon W & 632.500 \\
\hline$Z$ & -.55 \\
\hline Asymp. Sig. (2- & .578 \\
\hline tailed)
\end{tabular}

Kedua kelas memiliki kemampuan awal sama maka untuk mengetahui peningkatan kemampuan komunikasi matematis mahasiswa calon guru yaitu dengan menganalisis data $\mathrm{N}$-gain dengan langkahlangkah yang dilakukan sama dengan langkahlangkah diatas.

Tabel 5

Hasil Uji Normalitas N-gain kemampuan Komunikasi Matematis

\begin{tabular}{|l|r|r|r|}
\hline \multirow{2}{*}{} & \multicolumn{3}{|c|}{ Shapiro-Wilk } \\
\cline { 2 - 4 } & Statistic & \multicolumn{1}{c|}{ df } & \multicolumn{1}{c|}{ Sig. } \\
\hline N-gain eksperimen & .934 & 25 & .106 \\
N-gain kontrol & .968 & 25 & .597 \\
\hline
\end{tabular}

Data N-gain kelas eksperimen dan kelas kontrol berdistribusi normal. Karena data kedua kelas berdistribusi normal, maka analisis selanjutnya dilanjutkan dengan uji homogenitas.

Tabel 6

\section{Hasil Uji Homogenitas N-Gain Kemampuan Komunikasi Matematis}

\begin{tabular}{|c|r|r|r|}
\hline $\begin{array}{l}\text { Levene } \\
\text { Statistic }\end{array}$ & df1 & df2 & \multicolumn{1}{c|}{ Sig. } \\
\hline 1.454 & 5 & 10 & .287 \\
\hline
\end{tabular}

Data berdistribusi normal dan homogen, maka selanjutnya adalah untuk mengetahui peningkatan kemampuan komunikasi matematis mahasiswa calon guru yang belajar menggunakan pendekatan konstruktivisme dengan model pembelajaran generatif maka dilakukan uji perbedaan dua rerata.

Tabel 7

Hasil Uji Perbedaan Dua Rerata N-gain Kemampuan Komunikasi Matematis

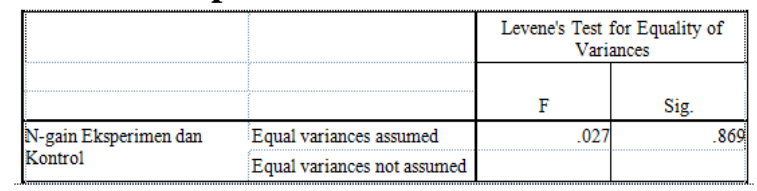

Berdasarkan data diatas pada Tabel 7 dapat dilihat bahwa nilai sig. 0,869. Karena analisis data menggunakan SPSS, maka nilai sig./2 (Uyanto, 2006 ) sehingga $0,869 / 2=0,43$, artinya nilai sig. > 0,05 dapat diartikan bahwa peningkatan kemampuan komunikasi matematis mahasiswa calon guru yang belajar menggunakan pendekatan konstruktivisme dengan model pembelajaran generatif lebih baik daripada peningkatan kemampuan komunikasi matematis mahasiswa calon guru yang belajar dengan cara biasa.

\section{Analisis Peningkatan Kemampuan Koneksi Matematis}

Untuk mengetahui peningkatan kemampuan koneksi matematis mahasiswa calon guru yang belajar menggunakan pendekatan konstruktivisme dengan model pembelajaran generatif dilakukan beberapa tahapan uji statistik pada data pretes dan $\mathrm{N}$-gain kemampuan koneksi matematis. Untuk mengetahui signifikansi kesamaan dua rerata skor pretes kemampuan koneksi mahasiswa calon guru maka dilakukan uji kesamaan dua rerata, yaitu dengan tahapan uji normalitas, uji homogenitas dan uji kesamaan dua rerata. 
Tabel 8

Hasil Uji Normalitas Pretes Kemampuan Koneksi Matematis

\begin{tabular}{|l|r|r|r|}
\hline & \multicolumn{3}{|c|}{ Shapiro-Wilk } \\
\cline { 2 - 4 } & Statistic & \multicolumn{1}{c|}{ df } & \multicolumn{1}{c|}{ Sig. } \\
\hline pretes eksperimen & .878 & 25 & .006 \\
\hline pretes kontrol & .914 & 25 & .037 \\
\hline
\end{tabular}

Uji normalitas kemampuan koneksi matematis tidak berdistribusi normal. Sehingga untuk analisis data selanjutnya dilanjutkan dengan uji non parametrik Mann Whitney.

Tabel 9

\section{Hasil Uji Mann Whitney Pretes Kemampuan Koneksi Matematis}

\begin{tabular}{|l|r|}
\hline & $\begin{array}{c}\text { pretes koneksi } \\
\text { eks dan kon }\end{array}$ \\
\hline Mann-Whitney U & 320.500 \\
\hline Wilcoxon W & 645.500 \\
\hline & -.317 \\
\hline Asymp. Sig. (2- & .751 \\
\hline tailed)
\end{tabular}

Kemampuan awal kedua kelas sama. Karena kemampuan awal koneksi matematis mahasiswa calon guru sama, maka untuk mengetahui peningkatan kemampuan koneksi matematis mahasiswa calon guru yaitu dengan menganalisis data $\mathrm{N}$-gain kemampuan koneksi matematis dengan langkah-langkah yang dilakukan sama dengan langkah-langkah diatas.

\section{Tabel 10}

\section{Hasil Uji Normalitas N-gain Kemampuan} Koneksi Matematis

\begin{tabular}{|l|r|r|r|}
\hline \multirow{2}{*}{} & \multicolumn{3}{|c|}{ Shapiro-Wilk } \\
\cline { 2 - 4 } & Statistic & df & \multicolumn{1}{c|}{ Sig. } \\
\hline K-gain Eksperimen & .973 & 27 & .695 \\
Koneksi & .835 & 27 & .001 \\
\hline
\end{tabular}

$\mathrm{N}$-gain tidak berdistribusi normal. Maka untuk uji statistik selanjutnya dilanjutkan dengan uji non parametrik Mann Whitney.

\section{Tabel 11}

\section{Hasil Mann Whitney N-Gain Kemampuan} Koneksi Matematis

\begin{tabular}{|l|r|}
\hline & N-gain \\
\hline Mann-Whitney U & 263.500 \\
\hline Wilcoxon W & 588.500 \\
\hline Z & -1.364 \\
\hline asymp. Sig. (2- & .17 \\
\hline
\end{tabular}

Peningkatan kemampuan koneksi matematis mahasiswa calon guru yang belajar menggunakan pendekatan konstruktivisme dengan model pembelajaran generatif lebih baik daripada peningkatan kemampuan koneksi matematis mahasiswa calon guru yang belajar dengan cara biasa.

\section{Analisis Hubungan Kemampuan Komunikasi Matematis dan Self-efficacy}

Untuk menganalisis hubungan antara kemampuan komunikasi matematis dan self-efficacy mahasiswa calon guru yaitu harus dianalisis uji normalitas terlebih dahulu pada data postes kemampuan komunikasi matematis dan self-efficacy mahasiswa calon guru. Jika kedua data berdistribusi normal maka dilanjutkan dengan uji korelasi Pearson, dan jika terdapat salah satu data atau kedua data tidak berdistribusi normal, maka dilanjutkan dengan uji korelasi Spearman.

Tabel 12

Hasil Uji Normalitas Postes Kemampuan Komunikasi Matematis dan Self-efficacy

\begin{tabular}{|l|r|r|r|}
\hline & \multicolumn{3}{|c|}{ Shapiro-Wilk } \\
\cline { 2 - 4 } & Statistic & \multicolumn{1}{|c|}{ df } & \multicolumn{1}{c|}{ Sig. } \\
\hline postes komunikasi \\
eksperimen
\end{tabular}

Berdasarkan Tabel 12 pada hasil uji normalitas kemampuan komunikasi matematis dan selfefficacy mahasiswa calon guru, terdapat nilai sig. $<0,05$ yaitu pada sig. postes komunikasi yaitu 0,009 . Sehingga data tidak berdistribusi normal. Maka untuk menganalisis hubungan antara kemampuan komunikasi matematis dan selfefficacy mahasiswa calon guru menggunakan uji korelasi Spearman.

Tabel 13

Hasil Analisis Uji Korelasi Spearman

\begin{tabular}{|c|c|c|c|c|}
\hline & & & komunikasi & self-efficacy \\
\hline \multirow[t]{6}{*}{ Spearman's rho } & \multirow[t]{3}{*}{ komunikasi } & Correlation Coefficient & 1.000 & .011 \\
\hline & & Sig. (2-tailed) & & .958 \\
\hline & & $\mathrm{N}$ & 27 & 27 \\
\hline & \multirow[t]{3}{*}{ self-efficacy } & Correlation Coefficient & .011 & 1.000 \\
\hline & & Sig. (2-tailed) & .958 & \\
\hline & & $\mathrm{N}$ & 27 & 27 \\
\hline
\end{tabular}

Berdasarkan Tabel 13 pada hasil analisis uji korelasi Spearman didapatkan nilai korelasi yaitu 0,011 yang berarti bahwa kekuatan hubungan antara kemampuan komunikasi matematis dan selfefficacy mahasiswa calon guru bernilai positif terdapat pada kulaifikasi sangat rendah (Sugiono, 
2007). Dari nilai sig. korelasi dapat terlihat nilai 0,958 , nilai sig tersebut $>0,05$ yang berarti bahwa Ho diterima artinya tidak terdapat hubungan antara kemampuan komunikasi matematis dan selfefficacy mahasiswa calon guru belajar menggunakan pendekatan konstruktivisme dengan model pembelajaran generatif.

\section{Analisis Hubungan Kemampuan Koneksi Matematis dan Self-efficacy}

Untuk menganalisis hubungan antara kemampuan koneksi matematis dan self-efficacy mahasiswa calon guru yaitu harus dianalisis uji normalitas terlebih dahulu pada data postes kemampuan koneksi matematis dan self-efficacy mahasiswa calon guru. Jika kedua data berdistribusi normal maka dilanjutkan dengan uji korelasi Pearson, dan jika terdapat salah satu data atau kedua data tidak berdistribusi normal, maka dilanjutkan dengan uji korelasi Spearman.

\section{Tabel 14}

\section{Hasil Uji Normalitas Postes Kemampuan Koneksi Matematis dan Self-efficacy}

\begin{tabular}{|l|r|r|r|}
\hline \multirow{2}{*}{} & \multicolumn{3}{|c|}{ Shapiro-Wilk } \\
\cline { 2 - 4 } & Statistic & \multicolumn{1}{c|}{ df } & \multicolumn{1}{c|}{ Sig. } \\
\hline koneksi & .928 & 27 & .063 \\
\hline
\end{tabular}

Berdasarkan Tabel 14 pada hasil uji normalitas kemampuan koneksi matematis dan self-efficacy mahasiswa calon guru, dapat terlihat bahwa nilai sig. > 0,05 yaitu 0,063 dan 0,673. Sehingga dapat disimpulkan bahwa data berdistribusi normal. Maka untuk menganalisis hubungan antara kemampuan koneksi matematis dan self-efficacy mahasiswa calon guru menggunakan uji korelasi Pearson.

\section{Tabel 15}

\section{Hasil Analisis Uji Korelasi Pearson}

\begin{tabular}{|ll|r|r|}
\hline & & koneksi & self-efficacy \\
\hline koneksi & Pearson Correlation & 1 & .027 \\
\cline { 2 - 4 } & Sig. (2-tailed) & & .895 \\
\cline { 2 - 4 } & $\mathrm{N}$ & 27 & 27 \\
\hline self-efficacy & Pearson Correlation & .027 & 1 \\
\cline { 2 - 4 } & Sig. (2-tailed) & .895 & \\
\cline { 2 - 4 } & $\mathrm{N}$ & 27 & 27 \\
\hline
\end{tabular}

Berdasarkan Tabel 15 pada hasil analisis uji korelasi Pearson didapatkan nilai korelasi yaitu 0,27 yang berarti bahwa kekuatan hubungan antara kemampuan komunikasi matematis dan selfefficacy mahasiswa calon guru rendah (Sugiono, 2007). Dari nilai sig. korelasi dapat terlihat nilai
0,895 , nilai sig tersebut $>0,05$ yang berarti bahwa H0 diterima, hal tersebut berarti bahwa tidak terdapat hubungan antara kemampuan koneksi matematis dan self-efficacy mahasiswa calon guru belajar menggunakan pendekatan konstruktivisme dengan model pembelajaran generatif.

\section{b. Pembahasan Hasil Penelitian}

Berdasarkan Analis data dan kajian teori yang telah dilakukan pada bab sebelumnya dapat dilihat bahwa kemampuan komunikasi dan koneksi matematis siswa baik pada kelas eksperimen maupun kelas kontrol tidak terdapat perbedaan pada sebelum pembelajaran. Pada kelas eksperimen siswa diberikan pembelajaran dengan menggunakan pendekatan konstrutivisme dengan model pembelajaran generatif yang di dalamnya memuat kerjasama juga mengusung lima tahap pola generatif yaitu tahap orientasi, tahap pengungkapan ide, tahap tantangan dan restruktursi, tahap penerapan, tahap review atau melihat kembali. Sedangkan kelas kontrol diberikan pembelajaran biasa yang dalam hal ini menggunakan pembelajaran konvensional. Namun berdasarkan hasil analisis data posstes dan n-gain didapatkan bahwa kemampuan komunikasi dan koneksi matematis mahasiswa calon guru yang menggunkan pembelajaran dengan pendekatan konstrktivisme dengan model pembelajaran generatif lebih baik dari pada pembelajaran biasa, begitupun dengan peningkatan kemempuan koneksi dan komunikasinyanya.

Ciri pendekatan kontruktivisme, seperti yang telah diungkapkan di bab sebelumnya adalah mengajukan pertanyaan, menemukan, komunitas belajar, menggunakan model, dan melaksanakan refleksi dan dikaitkan dengan lima tahapan yang berada pada model pembelajaran generatif. Tahaptahap tertentu yang perlu diperhatikan dalam teori belajar konstruktivisme, Hanbury (1996: 3) mengemukakan sejumlah aspek dalam kaitannya dengan pembelajaran matematika, yaitu (1) siswa mengkonstruksi pengetahuan matematika dengan cara mengintegrasikan ide yang mereka miliki, (2) matematika menjadi lebih bermakna karena siswa mengerti, (3) strategi siswa lebih bernilai, dan (4) siswa mempunyai kesempatan untuk berdiskusi dan saling bertukar pengalaman dan ilmu pengetahuan dengan temannya. Dan pada model pembelajaran generatif, Wittrock (1992) menyatakan bahwa model pembelajaran generatif merupakan suatu model pembelajaran tentang bagaimana seorang siswa membangun pengetahuan dalam pikirannya, seperti 
membangun ide tentang suatu fenomena atau membangun arti suatu istilah dan juga membangun strategi untuk sampai pada suatu penjelasan tentang pertanyaan bagaimana dan mengapa. Wittrock (Grabowski, 2001:720) mengonsepkan model pembelajaran generatif berdasarkan model neural dari fungsi otak dan telaah kognitif pada proses pengetahuan. Sehingga begitu pendekatan konstruktivisme dan model pembelajaran generatif ini disatukan maka tampak bahwa dapat meningkatkan kemampuan komunikasi juga koneksi matematis calon guru, hal tersebut dibuktikan dengan analisis data dan uji hipotesis yang dilakukan di BAB IV ini, yaitu tampak bahwa peningkatan kemampuan komunikasi dan koneksi calon guru yang pembelajarannya menggunkan konstruktivisme dengan model pembelajaran generatif lebih baik dari pada yang menggunakan pembelajaran biasa.

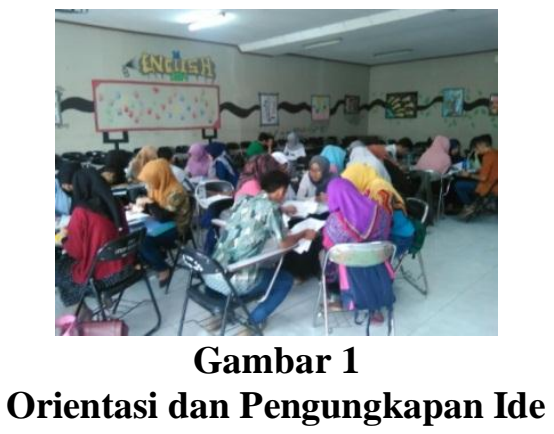

Tahap orientasi, merupakan tahap memotivasi mahasiswa untuk mempelajari materi yang akan diajarkan dengan mengaitkan manfaat materi tersebut di dalam kehidupan sehari-hari. Mahasiswa di dalam kelompoknya, diberikan kesempatan untuk membangun kesan mengenai konsep yang sedang dipelajari dengan menghubungkannya dengan pengalaman seharihari. Tujuannya agar dalam proses pembelajaran siswa dapat membayangkan sesuatu serta dapat memanfaatkan pengalaman dan pengetahuan yang telah dimilikinya untuk menyelesaikan masalah pada pokok bahasan yang sedang dihadapi, dengan demikian siswa termotivasi mempelajari pokok bahasan yang akan dipelajari. Dan dalam tahap pengungkapan ide, pada tahap ini narasumber dapat mengetahui ide atau konsep awal yang dimiliki mahasiswa mengenai materi geometri yang diajarkan. Mahasiswa diberikan kesempatan untuk mengemukakan ide mereka mengenai konsep yang dipelajari. Narasumber dalam hal ini dosen berperan sebagai motivator dengan cara mengajukan pertanyaan yang bersifat menggali pengetahuan mahasiswa (Socratic questioning) sehingga akan terungkap ide atau gagasan yang ada dalam benak siswa. Pertanyaan yang bersifat menggali dapat membantu mahasiswa menghargai kekurangan cara berpikir mereka dan mengkontruksi kembali gagasan mereka dengan cara yang lebih koheren atau bertalian secara logis.

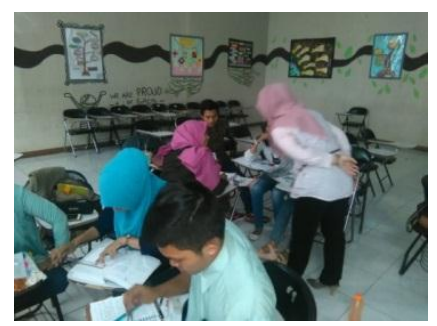

Gambar 2

Tahap Tantangan dan Restrukturisasi

Tahap Tantangan dan Restrukturisasi, pada tahap ini dosen memunculkan cognitive conflict dengan cara menyiapkan kondisi dimana mahasiswa diminta membandingkan pendapatnya dengan pendapat temannya, serta bisa mengupayakan mengungkapkan kebenaran/ keunggulan pendapatnya. Kemudian guru mengusulkan peragaan atau demonstrasi untuk menguji kebenaran pendapat mereka. Diharapkan selama proses ini muncul konflik antara apa yang dimiliki mahasiswa dengan apa yang dilihat dan diperagakan oleh dosen. Grobowski (2001) mengemukakan, "External stimuli arouse attention through the ascending reticular activating system. Without active, dynamic, and selective attending of an environmental stimulus, it follows that meaning generation cannot occur regarding that environmental stimulus." Setelah tahap tantangan tersebut diharapkan mahasiswa bisa memperoleh pemahaman baru yang lebih benar mengenai konsep yang bersangkutan. Supaya siswa mempunyai keinginan untuk mengubah struktur pemahaman mereka, siswa diberikan masalahmasalah yang menantang untuk membangkitkan keberaniannya dalam mengajukan pandapatnya dan berargumentasi tentang pokok bahasan yang sedang dipelajari.

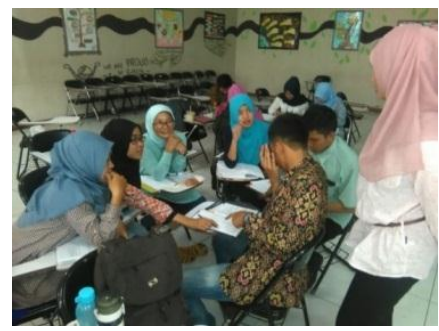

Gambar 3

Tahap Penerapan

Tahap selanjutnya dalam pembelajaran generatif adalah tahap penerapan, pada tahap ini mahasiswa 
menerapkan konsep awal yang mereka miliki ditambah konsep baru yang mereka peroleh pada permasalahan geometri dalam bentuk latihanlatihan soal. Mahasiswa diberikan kesempatan untuk memecahkan masalah yang lebih kompleks, menguji ide alternatif yang mereka bangun untuk menyelesaikan persoalan yang bervariasi. Kegiatan mahasiswa dalam fase terakhir ini antara lain adalah memecahkan soal-soal praktis berdasarkan konsep-konsep yang benar, menyajikan solusi dari suatu masalah kepada teman sejawatnya, berdiskusi dan beradu argumentasi tentang konsepkonsep yang benar, dan secara kritis mengevaluasi penggunaan konsep-konsep itu adalah situasi yang berbeda. Pada fase ini mahasiswa mengevaluasi dan membandingkan antara pengetahuan tentang konsep-konsep sebelumnya dengan konsep yang telah dikontruksi, dan mengadakan refleksi terhadap prosedur yang ditempuh. Selanjutnya dosen mengadakan review terhadap perubahanperubahan ide-ide mahasiswa sebagai hasil restrukturisasi terhadap gagasan atau ide awalnya.
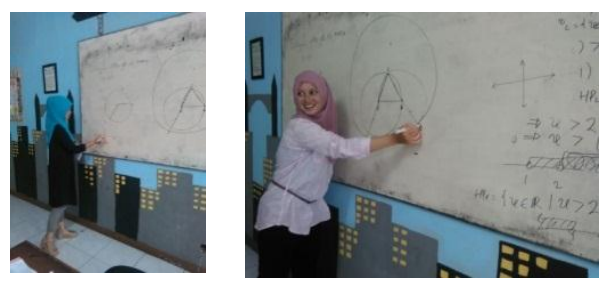

\section{Gambar 4 \\ Tahap Melihat Kembali}

Tahap terakhir adalah tahap melihat kembali. Mahasiswa diberi kesempatan untuk mengevaluasi kelemahan dari konsep yang dimilikinya, kemudian memilih cara/ konsep yang paling efektif dalam menyelesaikan permasalahan. Mahasiswa juga diharapkan dapat mengingat kembali konsep yang sudah dipelajari secara keseluruhan. Kondisi ini memberikan peluang kepada mahasiswa untuk mengungkap tentang apa yang sudah dan sedang dikerjakannya. Apakah yang dikerjakannya itu sudah sesuai dengan apa yang dipikirkannya.

Dalam belajar generatif mahasiswa sendirilah yang aktif membangun pengetahuannya, sedangkan dosen berperan sebagai fasilitator dan mediator dalam pembelajaran. Model pembelajaran generatif berbasis pada pandangan konstruktivisme, dengan asumsi dasar bahwa pengetahuan dibangun dalam pikiran mahasiswa itu sendiri.

Sedangkan pembelajaran yang dilakukan pada kelas kontrol, pembelajaran dilakukan dengan kovensinal dan dosen menjadi pusat aktivitas pembelajaran. Mahasiswa mencatat dan memperhatikan apa yang dikemukan oleh dosen.
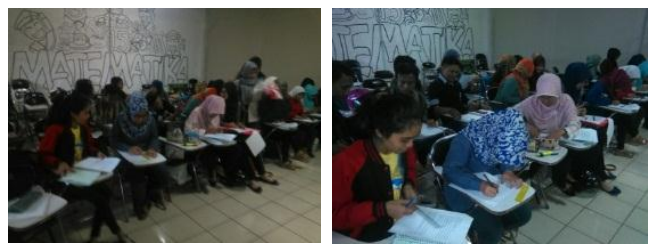

Gambar 5

\section{Pembelajaran di Kelas Kontrol}

Penelitian ini dilanjutkan dengan bagaimana pengaruh self eficacy terhadap kemampuan koneksi dan komunikasi matematis mahasiswa, self-efficacy sebenarnya mengarah pada "kepercayaaan dan kemampuan diri" untuk mengkoordinir, melaksanakan, dan mendapatkan hasil sesuai dengan yang diharapkan. Ketika seseorang memiliki self-efficacy yang baik,ia akan dapat meminimalisir dari berbagai bentuk kesalahan karena ia akan memikirkan dan merencanakan apa saja yang akan dilakukannya. Sehingga dapat dikatakan bahwa salah satu penunjang keberhasilan ialah dengan memiliki self-efficacy yang baik. Setelah dilakukan analisi korelasi antara kemampuan komunikasi dengan self-efficacy peneliti tidak mendapatkan hubungan yang positif itu. Hasil analisis uji korelasi Spearman didapatkan nilai korelasi yaitu 0,011 yang berarti bahwa kekuatan hubungan antara kemampuan komunikasi matematis dan selfefficacy mahasiswa calon guru bernilai positif terdapat pada kulaifikasi sangat rendah (Sugiono, 2007). Dari nilai sig. korelasi dapat terlihat nilai 0,958 , nilai sig tersebut $>0,05$ yang berarti bahwa Ho diterima artinya tidak terdapat hubungan antara kemampuan komunikasi matematis dan selfefficacy mahasiswa calon guru belajar menggunakan pendekatan konstruktivisme dengan model pembelajaran generatif. Dan begitupula pada kemampuan koneksi mahasiswa, nilai korelasi yaitu 0,27 yang berarti bahwa kekuatan hubungan antara kemampuan komunikasi matematis dan self-efficacy mahasiswa calon guru rendah (Sugiono, 2007). Dari nilai sig. korelasi dapat terlihat nilai 0,895 , nilai sig tersebut $>0,05$ yang berarti bahwa $\mathrm{HO}$ diterima, hal tersebut berarti bahwa tidak terdapat hubungan antara kemampuan koneksi matematis dan self-efficacy mahasiswa calon guru belajar menggunakan pendekatan konstruktivisme dengan model pembelajaran generatif. 


\section{PENUTUP}

\section{a. Kesimpulan}

Berdasarkan analisis data dan pembahasan yang dikemukakan pada Bab IV, dapat diambil beberapa kesimpulan sebagai berkut :

1) Peningkatan kemampuan komunikasi matematis mahasiswa calon guru yang pembelajarannya menggunakan pendekatan konstruktivisme dengan model generatif lebih baik dari pada yang menggunakan pembelajaran biasa.

2) Peningkatan kemampuan koneksi matematis mahasiswa calon guru yang pembelajarannya menggunakan pendekatan konstruktivisme dengan model generatif lebih baik dari pada yang menggunakan pembelajaran biasa.

3) Kekuatan hubungan antara kemampuan komunikasi matematis dan self-efficacy mahasiswa calon guru rendah. Berdasarkan nilai sig. korelasi terlihat tidak terdapat hubungan antara kemampuan komunikasi matematis dan self-efficacy mahasiswa calon guru belajar menggunakan pendekatan konstruktivisme dengan model pembelajaran generatif.

4) Kekuatan hubungan antara kemampuan koneksi matematis dan self-efficacy mahasiswa calon guru rendah. Berdasarkan nilai sig. korelasi terlihat tidak terdapat hubungan antara kemampuan koneksi matematis dan self-efficacy mahasiswa calon guru belajar menggunakan pendekatan konstruktivisme dengan model pembelajaran generatif.

\section{b. Saran}

Berdasarkan hasil penelitian, ada beberapa saran berhubungan dengan penelitian ini, antara lain:

1) Pembelajaran matematika dengan Pendekatan Konstruktivisme dengan model pembelajaran generatif baik dilakukan dikalangan mahasiswa, tetapi harus diperhatikan penggunaan waktu dan pembuatan instrumen yang cukup banyak.

2) Penelitian ini hanya terbatas pada geometri. Diharapkan pada peneliti lainnya untuk mengembangkan pada materi-materi pelajaran lainnya.

3) Sampel penelitian yang diambil hanya dua kelas sehingga hasil penelitian ini belum tentu sesuai dengan sekolah atau daerah lain yang memiliki karakteristik dan psikologi mahasiswa yang berbeda. Diharapkan kepada peneliti lainnya agar bisa menggunakan sampel yang lebih besar, dengan tujuan memperkecil kesalahan dan mendapatkan generalisasi yang lebih akurat.

\section{DAFTAR PUSTAKA}

Bandura, A. (1995). Self Efficacy : In Changing Societies. United Kingdom: Cambridge University.

Depdiknas. (2006). Kurikulum 2006 Standar Kompetensi Mata Pelajaran Matematika. Jakarta : Departemen Pendidikan Nasional.

Dewi, N.R. (2013). Peningkatan Kemampuan Koneksi Matematis Mahasiswa Melalui Brain-Based Learning Berbantuan Web. Prosiding SNMPM Universitas 11 Maret. [Online]. Vol 1 (13) 284 - 374. Tersedia: https://scholar.google.co.id/. $\quad[28$ januari 2016].

Fauzi, A.M, KMS. (2011). Peningkatan Kemampuan Koneksi Matematis dan Kemadirian Belajar Siswa dengan Pendekatan Pembelajaran Metakognitif di Sekolah Menengah Pertama. Tesis pada SPS UPI: Tidak diterbitkan.

Fitriandini,V.(2009). Pengaruh Model pembelajaran Generatif terhadap Hasil Belajar Matematik Siswa SMA.Bandung: Skripsi FKIP UNPAS Bandung : Tidak diterbitkan.

Grabowski, B.L. (2001). Generative Learning Contributions to The Design of Instruction and Learning. Pennsylvania: Penn State University.

Hanbury, L. 1996. Constructivism: So What? In J. Wakefield and L. Velardi (Eds.). Celeberating Mathematics Learning (pp.3 8). Melbourne: The Mathematical Assciation of Victoria.

Hudoyo, H. 1998. Pembelajaran Matematioka Menurut Pandangan Konstruktivistik. Makalah Disajikan dalam Seminar Nasional Upaya Meningkatkan Peran Pendidikan Matematika dalam Menghadapi Era Globaliasasi. PPS IKIP Malang: Tidak Diterbitkan.

Hulukati,E. (2005). Mengembangkan Kemampuan Komunikasi dan Pemecahan Masalah Matematik Siswa SMP melalui Model Pembelajaran Generatif. Bandung: Disertasi PPs UPI. Tidak diterbitkan.

Marrison,G. (2011). The Implications of Generative Learning Strategies For Integrating Cognitive Load And Selfregulation Theory Into Educational Innovations. Old Dominion University. [online]: 
http://www.icsei.net/icsei2011/Full\%20Pape rs/0108_B.pdf

NCTM. (1989). Curriculum and Evaluation Standards for School Mathematics. Reston, VA : NCTM.

Nurhadi. 2004. Pembelajaran kontekstual dan Penerapan dalam KBK. Malang: Universitas Negeri Malang.

Poedjiadi, A. (1999). Pengantar Filsafat Ilmu bagi Pendidik. Bandung: Yayasan Cendrawasih.

Rachmawati, E.Y. (2012). Hubungan Antara Selfefficacy dengan Kematangan Karir pada Mahasiswa Tingkat Awal dan Tingkat Akhir di Universitas Surabaya. Calyptra:Jurnal Ilmiah Mahasiswa Universitas Surabaya. [Online]. Tersedia:http://journal.ubaya.ac.id/index.p hp/jimus/article/view/30. [28 Januari 2016].

Ruseffendi, E.T.(1994). Dasar-dasar Penelitian dan Pendidikan Bidang Non Eksakta Lainnya. Cetakan Pertama.Semarang. IKIP Semarang Press.

.(2006). Pengantar kepada Membantu Guru Mengembangkan Kompetensinya dalam Pengajaran Matematika untuk Meningkatkan CBSA. Bandung: Tarsito.

Setiadi, R. (2010). SELF-EFFICACY In Indonesian Literacy Teaching Context: A Theoretical and Empirical Perspective. Bandung: Rizqi Press.

Son, AL. (2015). Pentingnya Kemampuan Komunikasi Matematika Bagi Mahasiswa Calon Guru Matematika. Jurnal Wiraloda. [Online]. Vol. 7 (15) 4-5. Tersedia: https://www.google.com/search?q=indikat or+kemampuan+komunikasi+mahasiswa\& ie $=$ utf- $8 \&$ oe $=$ utf-

$8 \& \mathrm{aq}=\mathrm{t} \& \mathrm{rls}=$ org.mozilla:en-

US:official\&client=firefox-

a\&channel=fflb. [ 28 januari 2016]

Sugiono. (2007). Metode penelitian Pendidikan Pendekatan Kuantitatif, Kualitatif dan $R \& D$. Bandung: Alfabeta.

Sumarmo,U. (2005). "Pembelajaran Matematika untuk Mendukung Pelaksanaan Kurikulum Tahun 2002 Sekolah Menengah". Makalah disajikan pada seminar Pendidikan Matematika di FPMIPA Universitas Negeri Gorontalo tanggal 7 Agustus 2005.

Sumarmo, U. (2010). Berfikir dan Disposisi: Apa, Mengapa dan Bagaimana Dikembangkan pada Peserta Didik. FPMIPA UPI: Tidak diterbitkan.
Sumarmo, U. (2012). Bahan Ajar Matakuliah Proses Berpikir Matematik Program S2 Pendidikan Matematika STKIP Siliwangi 2012. Bandung: diterbitkan.

Tytler, R. (1996). Constructivism and Conceptual Change View of Learning in Science. Majalah Pendidikan IPA: Khasanah Pengajaran IPA. Bandung: IMAPIPA.

Uyanto, S.S. (2006). Pedoman Analisis Data dengan SPSS Edisi ke-2. Yogyakarta: Graha Ilmu.

Wheatley, G. H. (1991). Constructivist Perspective on Science and Mathematics Learning. Journal of Research in Science Teaching. New York: John Wiley \& Sons, Inc. 35 (1).

Wittrock, M.C.(1992). Generative Learning Processes of The Brain. Los Angeles: University of California. Educational Psychologist. 